\title{
PATULIN ACCUMULATION IN APPLES DURING STORAGE BY PENICILLIUM EXPANSUM AND PENICILLIUM GRISEOFULVUM STRAINS
}

\author{
Juliane Elisa Welke $^{1 *}$, Michele Hoeltz ${ }^{1}$, Horacio Alberto Dottori ${ }^{2}$, Isa Beatriz Noll ${ }^{1}$ \\ ${ }^{1}$ Instituto de Ciência e Tecnologia de Alimentos, Universidade Federal do Rio Grande do Sul, Porto Alegre, RS, Brasil; ${ }^{2}$ Instituto \\ de Física, Universidade Federal do Rio Grande do Sul, Porto Alegre, RS, Brasil.
}

Submitted: August 25, 2009; Returned to authors for corrections: April 23, 2010; Approved: June 21, 2010.

\begin{abstract}
A part of apples destined to juice production is generally of poor quality. Apples from cold storage or recently harvest (ground harvested or low quality apples) are stored under ambient conditions until they are processed. Since Penicillium expansum and P. griseofulvum are the principal fungal species isolated from stored apples in Brazil, the objective of this study was to investigate the ability of these strains to produce patulin in apples and report the consequences of this type of storage in loss of quality. The toxin was quantified using thin layer chromatography and charge-coupled device camera (TLC-CCD). The rate and quantities that $P$. expansum and $P$. griseofulvum can grow and produce patulin are highly dependent on the fungal strain and time. Lesion diameter resulted to be independent of the strain considered. The maximum period of time which apples were kept at cold storage $\left(4^{\circ} \mathrm{C}\right)$ without patulin accumulation was 27 days. When these apples were kept at $25{ }^{\circ} \mathrm{C}$ during 3 days, both factors lesion diameter and patulin production increased significantly. These results confirm that time in which apples are taken out from cold storage room before juice production is critical in order to prevent patulin accumulation.
\end{abstract}

Key words: Patulin; Apple; Penicillium expansum; Penicillium griseofulvum

\section{INTRODUCTION}

Penicillium spp. are the major responsible of fruit decaying in stored apples (18). $P$. expansum and $P$. griseofulvum produce patulin, a mycotoxin. Patulin (4hydroxy-4H-furo[3,2c]pyran,2[6H]-one) has been reported as mutagenic and cause neurotoxic, immunotoxic and gastrointestinal effects in animals $(4,19)$. Moreover patulin is a potential genotoxic with ability to induce oxidative DNA damage in human cells, which is considered to play a role in mutagenesis and cancer initiation (8). Patulin is found mainly in low quality apples diverted to production of apple byproducts. This toxin is an unsaturated heterocyclic lactone and it is highly stable in acidic conditions, such as those found in apple-based products.

Due to its toxicity and the possibility of using patulin as a quality indicator in foods, the Codex Alimentarius Commission has considered acceptable a maximum concentration of 50 $\mu \mathrm{g} . \mathrm{L}^{-1}$ of patulin in apple juice. In European Union the maximum level allowed for apple products intended for infants and young children is $10 \mu \mathrm{g} \cdot \mathrm{kg}^{-1}(21)$.

P. expansum is a psychotropic mould and the most 
common pathogens of fruits; it causes blue mold rot on fruits, especially apples during storage $(15,22)$. Damaged and mature fruits show the greatest susceptibility to this mould. Postharvest spoilage of fruits results in abbreviated shelf-life and significant economic losses to the fruit industry. Since $P$. expansum and $P$. griseofulvum are the principal fungal species isolated from cold stored apples in Brazil, it is important to know the influence of different storage conditions on its ability to growth and produce patulin in apples (23).

Some works have studied the decay caused by $P$. expansum in apples $(2,12,13,18)$. Six different varieties of apples (Red Delicious, Golden Supreme, Gala, Fuji, Empire and McIntosh) were inoculated with $P$. expansum spores and the varieties which it showed the highest patulin concentration were Golden Supreme (54.2 $\mu \mathrm{g} . \mathrm{Kg}^{-1}$ ) and McIntosh (52.1 $\left.\mu \mathrm{g} . \mathrm{Kg}^{-1}\right)$ (18). The growth of $P$. expansum was higher in pears than in apples, however the latter tend to accumulate more patulin (12). The effect of $\mathrm{pH}$ was also evaluated in apples and patulin production increased from $\mathrm{pH} 2.5$ to $\mathrm{pH} 3.5$ and then remained constant until $\mathrm{pH}$ 5.5. Although $\mathrm{pH}$ influences patulin accumulation, other factors such as organic acid content and the degree of ripeness of the fruit may play an important role in patulin accumulation (13). Baert et al. (2) evaluated the $P$. expansum growth in apples at 2, 4, 7, 10, 12, 16, 20, 25 and $30{ }^{\circ} \mathrm{C}$ and the optimal growth was at $25^{\circ} \mathrm{C}$ and even at $2{ }^{\circ} \mathrm{C}$ the growth of this fungus was observed. However there is no information about the minimum and optimal temperature for the growth of $P$. griseofulvum in apples. The controlled atmospheres do not influence the growth of $P$. expansum, but patulin production was strongly influenced (2). On the other hand, no study is focused on simulation of storage conditions of apples contaminated with $P$. griseofulvum. Therefore there is no literature about the establishment of the maximum time of storage under refrigeration of apples contaminated with $P$. expansum and $P$. griseofulvum strains.

In some cases, part of apples harvested is not suitable for fresh market because of their low quality. These apples are generally used to production of juice. Some juice industries keep apples in open deck storage for considerable periods of time before the processing. In apple products production, patulin is accumulated before industrial processing begins (29).

The aim of this study was to investigate the ability of different strains of $P$. expansum and $P$. griseofulvum to produce patulin in apples incubated at $25{ }^{\circ} \mathrm{C}$ and cold stored at $4{ }^{\circ} \mathrm{C}$ and evaluate the loss of quality of apples.

\section{MATERIAL AND METHODS}

\section{Fruits}

In total, 105 apples of variety Fuji from 2007 season were used in this study. Only undamaged and disease-free fruit were used in the experiments. Apples were surface disinfected with $2 \%(\mathrm{w} / \mathrm{v})$ sodium hypochlorite solution for $1 \mathrm{~min}$ and rinsed with sterile water for three times. Average weight and caliber per apple were $190 \mathrm{~g}$ and $80.8 \mathrm{~mm}$, respectively.

\section{Isolates}

Four strains of $P$. expansum (PE39, PE45, PE51 and PE8) and two strains of $P$. griseofulvum (PG30 and PG12) isolated from cold stored apples in Brazil were used. The isolates were previously confirmed to belong to these Penicillium species according to Pitt and Hocking (1997). The strains were stored in potato dextrose agar (PDA) tubes at $4{ }^{\circ} \mathrm{C}$ in Institute of Food Science and Technology of the Federal University of Rio Grande do Sul.

\section{Patulin production by Penicillium isolates}

For testing patulin production, isolates of Penicillium were grown on yeast extract sucrose medium (YES) and Malt Extract Agar (MEA) for 7 days at $25{ }^{\circ} \mathrm{C}$ in dark. After this period, entire colony were transferred to vials containing 10 $\mathrm{mL}$ of extraction solvent (chloroform: methanol, 2:1, v/v) and mixed in vortex for at least $1 \mathrm{~min}$. Thirty microliter aliquots of extracts and patulin standard $\left(10 \mu \mathrm{g} \cdot \mathrm{mL}^{-1}\right)$ were spotted on thin layer chromatography (TLC) plates (SIL G-25HR, MacheryNagel and Co., Germany). The spots were dried, and the plates developed in solvent system toluene:ethylacetate:formic acid $(5: 4: 1 \mathrm{v} / \mathrm{v} / \mathrm{v})$. 
For identification of patulin, the TLC plates were sprayed with $0.5 \%$ aqueous methyl-benzothiazolinone hydrazone hydrochloride monohydrate (MBTH) (Fluka, USA) and heated at $130{ }^{\circ} \mathrm{C}$ for $15 \mathrm{~min}$. Patulin appeared as a yellow spot under visible light for reflection and transparency at the same time and a yellow-orange fluorescence spot under long wavelength UV light (366 nm). The TLC plate was sprayed with water$90 \%$ formic acid (98:2 v/v) until the layer appeared wet, and was left at room temperature for $30 \mathrm{~min}$ and then observed under $366 \mathrm{~nm}$ UV light, which improved the visualization of the yellow-orange fluorescence spots against the background (10). The strains of $P$. expansum (PE39, PE45, PE51 and PE8) and P. griseofulvum (PG30 and PG12) proved to be patulin producers.

\section{Inoculum preparation}

For inoculum preparation, firstly the fungus were inoculated on YES and incubated at $25^{\circ} \mathrm{C}$ until sporulation. A conidial suspension was prepared in Tween 80 in sterile water $(0.005 \%, \mathrm{v} / \mathrm{v})$. The concentration of the conidial suspension was determined using a Neubauer chamber and was adjusted with Tween 80 solution until a final concentration of $10^{6}$ conidia. $\mathrm{mL}^{-1}$. Thirty microliter of conidial suspension was injected with a sterile syringe in the apple at a depth of $1 \mathrm{~cm}$. Apples were placed in sterile $500 \mathrm{~mL}$ glass containers.

\section{Storage treatments}

Eighty four apples were incubated for 1, 3, 5 and 7 days at $25^{\circ} \mathrm{C}$. Twenty one apples were stored for 30 days at $4{ }^{\circ} \mathrm{C}$ and after this period were kept at $25{ }^{\circ} \mathrm{C}$ during 3 days to simulate the time that apples are kept at ambient temperature in transport or storage before processing. Apples stored at $4{ }^{\circ} \mathrm{C}$ were periodically checked until fungal growth was observed. To prevent anaerobic conditions being generated due to the respiration of the apples and fungi, the containers were opened in a sterile environment every day for apples stored at $25{ }^{\circ} \mathrm{C}$ and every 5 days for apples stored at $4{ }^{\circ} \mathrm{C}$. Each experiment in each tested temperature and time was done in triplicate. The lesion diameters were measured after each storage time. A control was done for each storage treatment (sterile water with $0.005 \%$ of Tween 80$)$.

\section{Analysis of patulin accumulation in apples by Penicillium strains}

A modified version of the method used by Welke et al. (27) was used. In order to determine patulin accumulation, necrosed tissue was removed from the apple. Considering that patulin can diffuse to the sound tissue, apple flesh was cut $1 \mathrm{~cm}$ below the decayed tissue. The samples were weighed and analyzed immediately.

Distilled water was added to the decayed portion in 1:1 (w/w) relation. Patulin was extracted with $20 \mathrm{~mL}$ of ethyl acetate by mixing vigorously for 1 min using a vortex. Then 10 $\mathrm{mL}$ of sodium carbonate solution $(1.5 \%, \mathrm{w} / \mathrm{v})$ was added to organic phases to remove phenolic acids. Extracted samples were dried with anhydrous sodium sulfate and transferred to a silica gel column prepared in a glass tube filled with $8 \mathrm{~g}$ of Silicagel (60, 70-230 mesh, Merck). The toxin was eluted from the column with $10 \mathrm{~mL}$ of ethyl acetate. After solvent evaporation, the extract was dissolved in $100 \mu \mathrm{L}$ of chloroform. The clean-up procedure using silicagel column had already been used by Kawashima et al. (8) and Oliveira et al. (16) in patulin determination of tomato pulp and grapes, respectively.

Five, ten and twenty microliter aliquots of sample extract and patulin standard solution $\left(10 \mu \mathrm{g} . \mathrm{mL}^{-1}\right)$ were spotted $1 \mathrm{~cm}$ apart on TLC plates. The spots were dried, and the plates developed in solvent system toluene:ethyl acetate:formic acid $(5: 4: 1 \mathrm{v} / \mathrm{v} / \mathrm{v})$. Patulin identification was done according to Martins et al. (11).

The quantification of the fluorescence intensities from UV lamp were recorded by a charge-coupled device (CCD) camera (Sony, model DSC-H50, Tokyo, Japan) according to Hoeltz et al. (6). Images were taken in each experiment and were analyzed using IMSTAT software (Image Statistics) of IRAF (Image Reduction Astronomical Facility, http://acs.pha.jhu. edu/ shy/x-iraf-windows/) package. Equivalent results can be achieved with the package ImageJ (Image Processing and Analysis in Java, http://rsbweb.nih.gov/ij/). 
The recovery rates obtained by spiking the apple with 200 , 300 and $400 \mu \mathrm{g}$ of patulin per $\mathrm{kg}$ in triplicate were 91, 92 and $88 \%$ respectively and the relative standard deviation (RSD) for repeatability was $4.3,6.2$ and 4.2, respectively. The limit of detection (LOD) was $0.005 \mu \mathrm{g}$ per spot and the limit of quantification (LOQ) was $14 \mu \mathrm{g} \cdot \mathrm{kg}^{-1}$. Linearity was determined by analyzing six calibration standards within the concentration ranging from 45 to $2100 \mu \mathrm{g} \cdot \mathrm{kg}^{-1}$. The correlation coefficient was 0.996.

\section{Patulin Standard Solution}

A stock standard solution of patulin was prepared by dissolving $5 \mathrm{mg}$ of pure crystalline patulin (Sigma) in chloroform at concentration of $100 \mu \mathrm{g} \cdot \mathrm{mL}^{-1}$. The standard solution was kept frozen $\left(-18{ }^{\circ} \mathrm{C}\right)$. The concentration of the patulin stock solution was determined by measuring the UV absorbance at $275 \mathrm{~nm}$ and calculated by using the molar extinction coefficient $\varepsilon$ of 14600 . The concentration of working standard solution in chloroform was $10 \mu \mathrm{g} \cdot \mathrm{mL}^{-1}(1)$.

\section{Statistical analysis}

The lesion diameters and patulin produced for each strain were evaluated by analysis of variance (ANOVA) at $\mathrm{p}<0.05$ using $\mathrm{R}$ programming language for statistic (www.rproject.org). This software is freely available and it is appropriate for the current application. Seven strains including $P$. expansum and $P$. griseofulvum were tested in order to evaluated the correlation between strain, lesion diameter and patulin production.

\section{RESULTS AND DISCUSSION}

The present assay studied the consequences of temperature and time of storage in development of lesions and patulin accumulation. The ability to produce patulin of different strains of $P$. expansum and $P$. griseofulvum was investigate in apples incubated at $25{ }^{\circ} \mathrm{C}$ and cold stored at $4{ }^{\circ} \mathrm{C}$. These temperatures were chosen to evaluate the storage at ambient or refrigeration temperature that apples are kept before juice production. The loss of quality was reported through the measuring as lesion diameter which it is related to the capability of the mould to colonize apple. The Fuji apple variety was chosen for this study because it is one of the most cultivated in Brazil.

No lesions were detected in control apples either after incubation at $25{ }^{\circ} \mathrm{C}$ or cold storage $\left(4^{\circ} \mathrm{C}\right)$. Although the progress of decay was variable, infection of apples with conidial suspensions resulted in lesions in all the apples. The ANOVA test showed that lesion size did not depend on strains $(\mathrm{p}=0.8524)$. Lesion diameter increased as a function of time and the same profile was observed for all strains (Figure 1). Significantly bigger sizes of lesions were observed when apple were kept at $25{ }^{\circ} \mathrm{C}$ after 7 days. After this period, lesion size was more than half of the apple.

\section{Strain PE39}

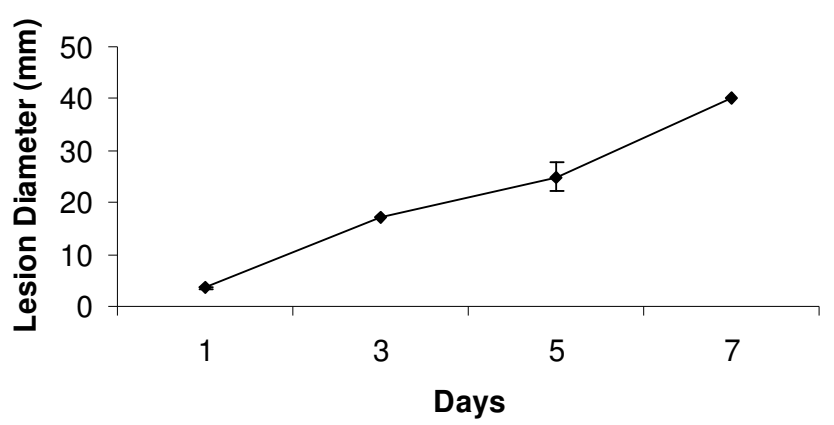

Strain PE45

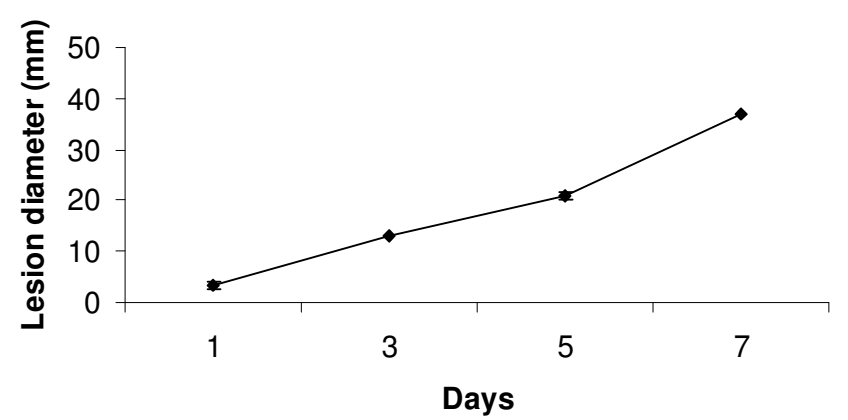


Strain PE51

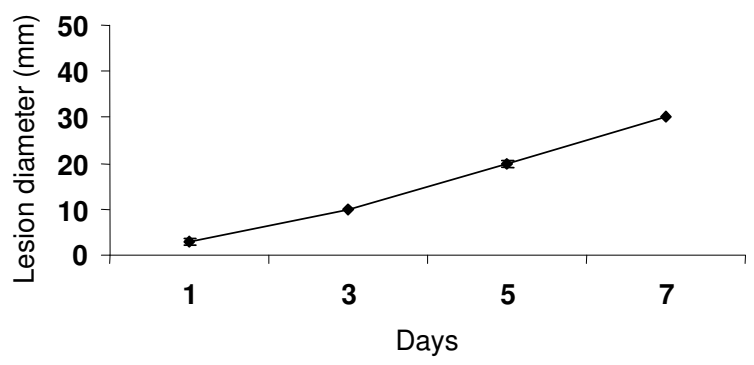

Strain PG30

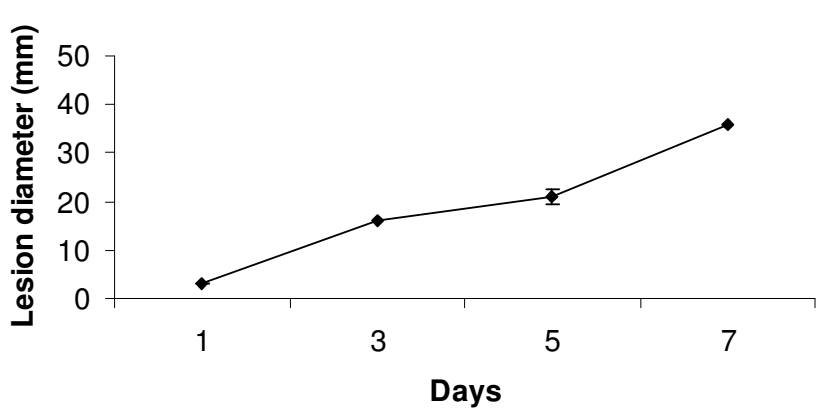

Strain PE8

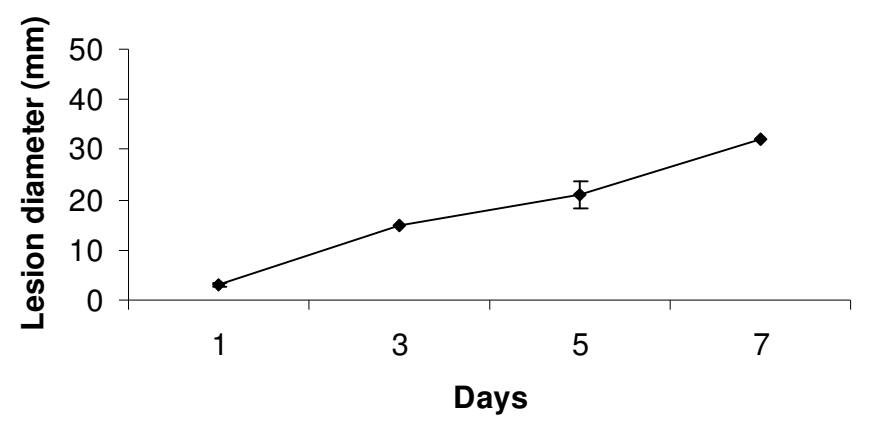

Strain PG12

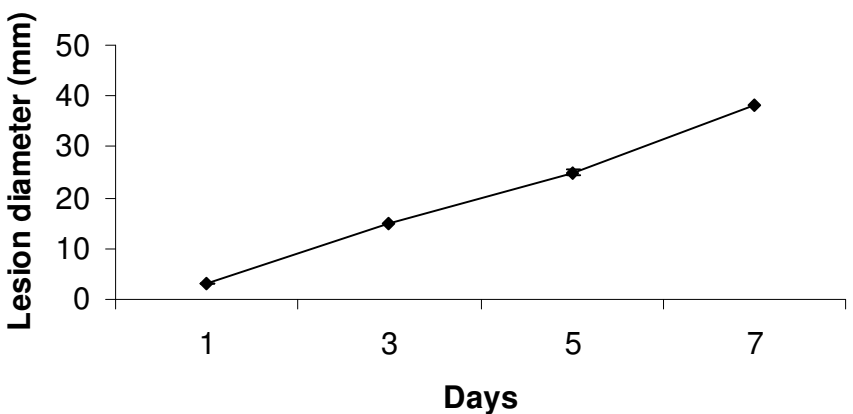

Figure 1. Lesion diameters growth at $25^{\circ} \mathrm{C}$ for $1,3,5$ and 7 days in apples inoculated with P. expansum (strains PE39, PE45, PE51 and PE8) and P. griseofulvum (strains PG30 and PG12) (error bars represent mean \pm standard deviation).

At $25^{\circ} \mathrm{C}$, the patulin production by $P$. expansum and $P$. griseofulvum increased as a function of time (Figure 2) and consequently also as a function of the lesion diameter. No significant differences were observed in patulin produced by the strains tested after $1,3,5$ and 7 days at $25^{\circ} \mathrm{C}(\mathrm{p}=0.103)$. The patulin production at $25^{\circ} \mathrm{C}$ in Fuji apples began 16 hours after inoculation of Penicillium strains. After a day at $25^{\circ} \mathrm{C}$, patulin levels produced by $P$. expansum and $P$. griseofulvum strains ranged from 29 to $282 \mu \mathrm{g} \cdot \mathrm{kg}^{-1}$. Thus, apples contaminated with Penicillium strains, confirmed to be patulin producers, will have high patulin levels if they remain a day at ambient storage before apple processing.
Strain PE39

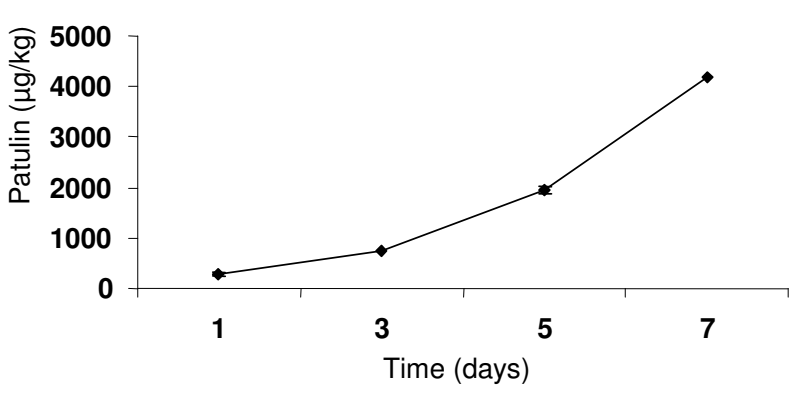

Strain PE45

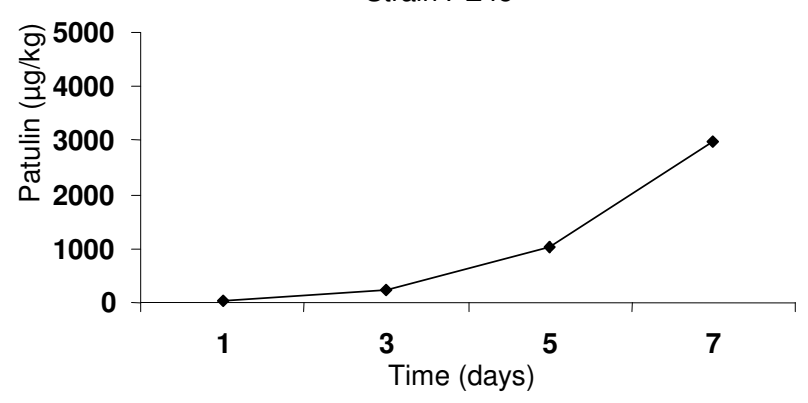




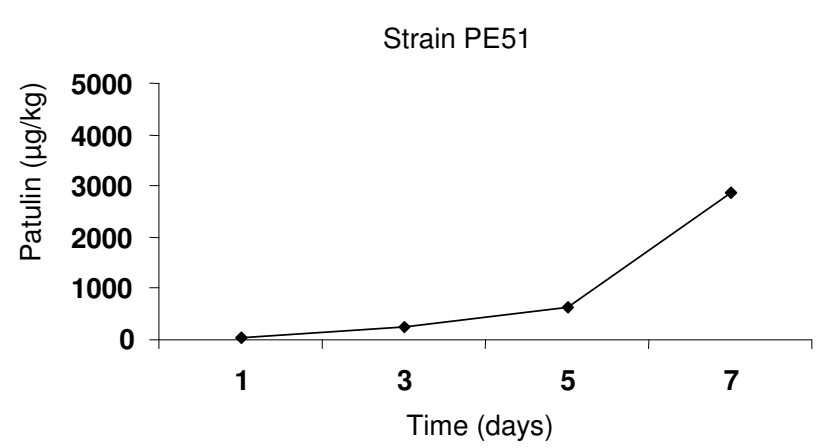

Strain PG30

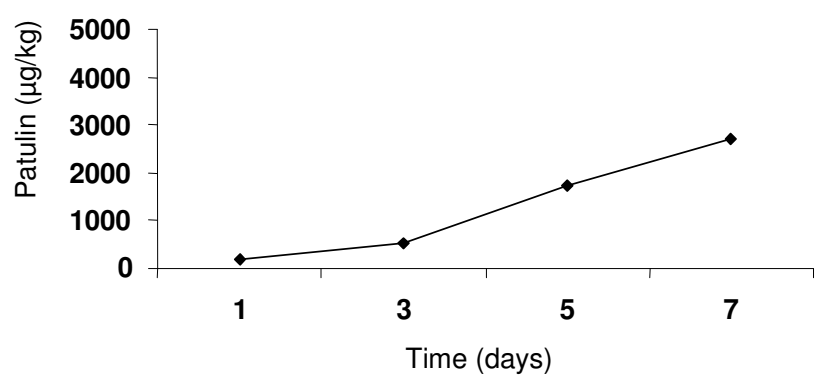

Strain PE8

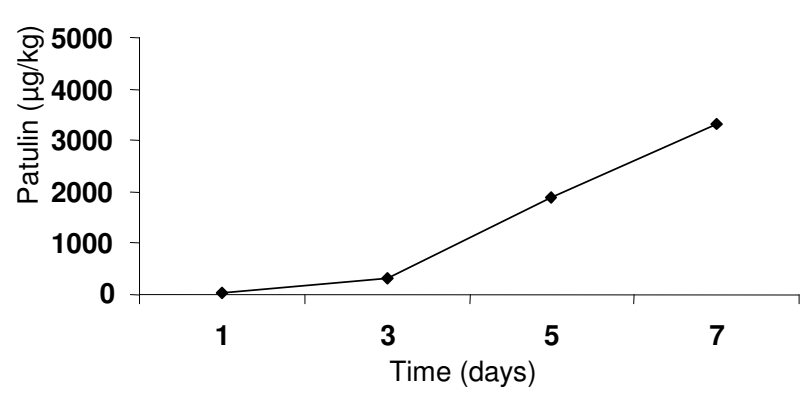

Strain PG12

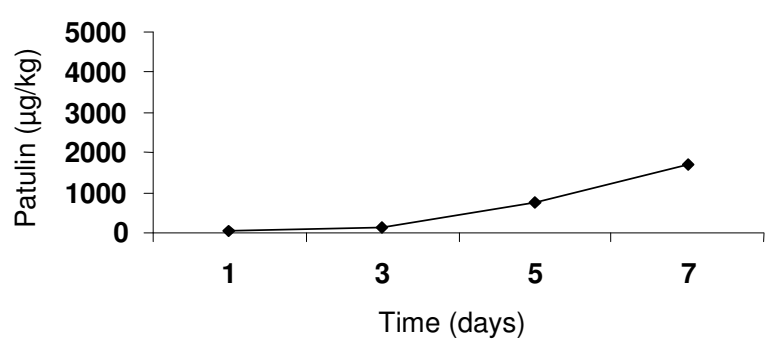

Figure 2. Patulin production by P. expansum (strains PE39, PE45, PE51 and PE8) and P. griseofulvum (strains PG30 and PG12) in apples at $25^{\circ} \mathrm{C}$ after $1,3,5$ and 7 days (error bars represent mean \pm standard deviation).

P. expansum (PE39) produced higher patulin content than the other strains $\left(4193 \pm 294 \mu \mathrm{g} \cdot \mathrm{kg}^{-1}\right)$ after 7 days at $25{ }^{\circ} \mathrm{C}$. PE51 on the other hand was the $P$. expansum strain which produced lower patulin content $\left(2883 \pm 578 \mu \mathrm{g} \cdot \mathrm{kg}^{-1}\right)$ after 7 days at $25{ }^{\circ} \mathrm{C}$. Considering only $P$. griseofulvum strains, PG12 and PG30 produced $1700 \pm 90 \mu \mathrm{g} \cdot \mathrm{kg}^{-1}$ and $2700 \pm 150 \mu \mathrm{g} \cdot \mathrm{kg}^{-1}$, respectively.

When apples are infected with fungal spores it is quite difficult to avoid fruit spoilage even if fruits are stored at low temperatures (5). In our assay, patulin was produced in apples at $4{ }^{\circ} \mathrm{C}$ only after 27 days by some strains of $P$. expansum and P. griseofulvum (PE39, PE45, PG30 and PG12), but levels produced were low $\left(22 \pm 3,70 \pm 10,47 \pm 9,11 \pm 4 \mu \mathrm{g} \cdot \mathrm{kg}^{-1}\right.$ respectively). The maximum period of time which apples were kept at cold storage $\left(4{ }^{\circ} \mathrm{C}\right)$ without patulin accumulation was 27 days.

In apples kept at $4{ }^{\circ} \mathrm{C}$ for 30 days it was possible to see small lesion diameter, even for the strains that produced no patulin. Thus, growth of $P$. expansum during cold storage is not prevented although it is significantly reduced.

At $4{ }^{\circ} \mathrm{C}$, patulin content increased with the increase of lesion diameter. No significant difference was observed between strains of $P$. expansum and $P$. griseofulvum in relation to lesion diameter $(\rho=0.01)$. The lesion diameter was higher than $3 \mathrm{~mm}$ after 30 days at $4{ }^{\circ} \mathrm{C}$ for all strains. After this period the apples were kept at $25{ }^{\circ} \mathrm{C}$ during 3 days. We observed that both factors lesion diameter and patulin production increased significantly (Figure 3a). The storage of apples for 3 days at 25 ${ }^{\circ} \mathrm{C}$ led to an average growth of lesion diameter of more than seven times comparing with the lesion observed at the end of cold storage. This represents the loss of quality of apples increased considerably during the storage without refrigeration. In apples kept at $25^{\circ} \mathrm{C}$ for 3 days (after cold storage at $4{ }^{\circ} \mathrm{C}$ for 30 days), the lesion diameters caused by strains PE39, PE45, PE51, PE8, PG30 and PG12 were $37 \pm 1,35 \pm 2,24 \pm 1.8,22 \pm$ $1.9,31 \pm 1.3$ and $33 \pm 1.6 \mathrm{~mm}$ respectively.

In relation of patulin levels, the patulin produced at $4{ }^{\circ} \mathrm{C}$ for 30 days by strains PE39, PE45, PG30 and PG12 were $40 \pm$ 
$4,82 \pm 10,69 \pm 10,23 \pm 7 \mu \mathrm{g} \cdot \mathrm{kg}^{-1}$ respectively. The results showed that in apples kept for 3 days at $25{ }^{\circ} \mathrm{C}$ after cold storage occurred a stimulation of the patulin production (Figure 3b). The inverse procedure was done by McCallum et al. (12) who observed a decrease in patulin concentration when the temperature was decreased from 25 to $4{ }^{\circ} \mathrm{C}$. Northold et al. (15) also observed a decrease in patulin levels when temperature was from 20 to $4{ }^{\circ} \mathrm{C}$. Therefore it was not in accordance to Baert et al. (2) who concluded that lowering the temperature from 20 to $4{ }^{\circ} \mathrm{C}$ causes higher patulin levels for some strains. Based on the presented results and other studies $(2,12,15)$ it can be concluded that temperature which apples are stored influence on mould growth rate, patulin production and consequently on the fruits shelf life. (a)

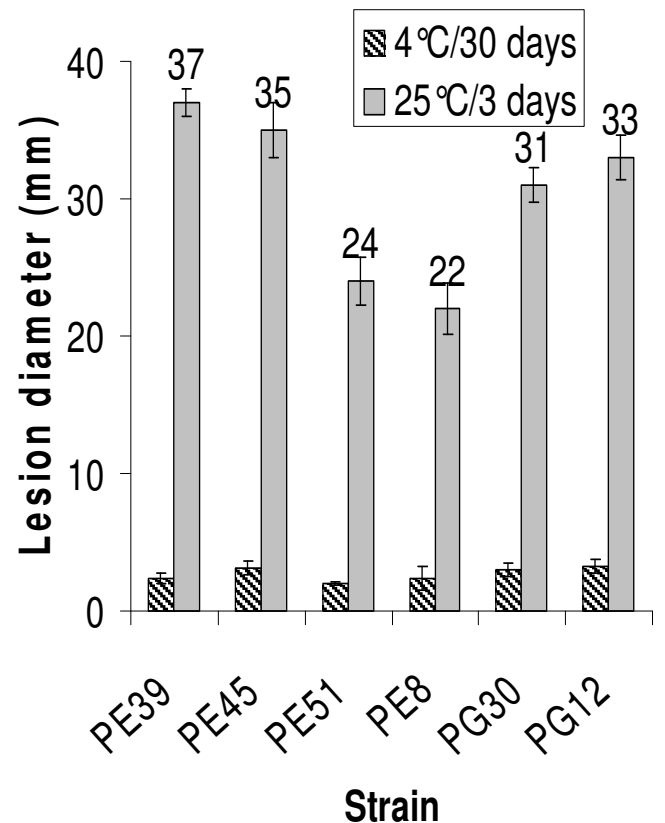

(b)

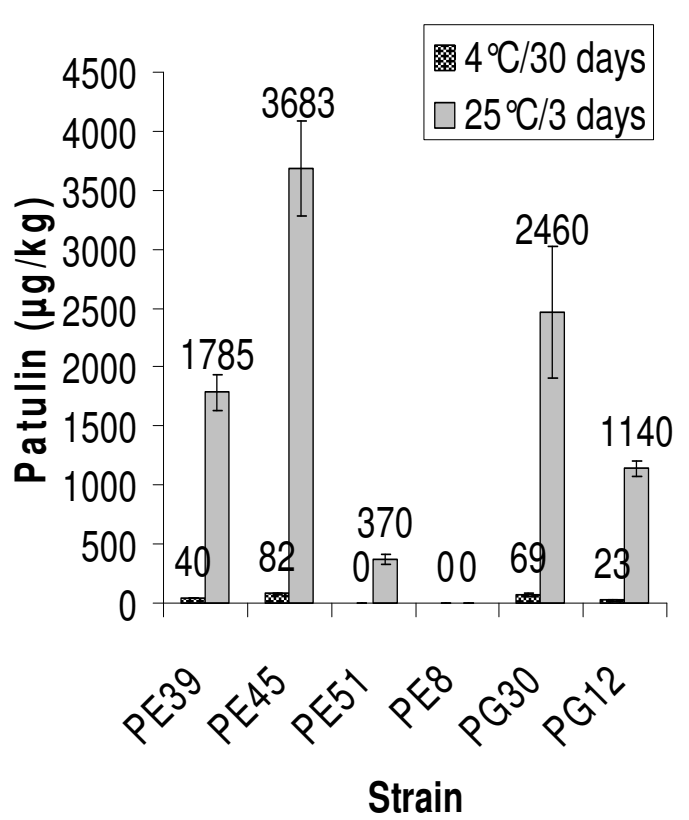

Figure 3. Lesion diameters (a) and patulin production (b) by strains of P. expansum (strains PE39, PE45, PE51 and PE8) and P. griseofulvum (strains PG30 and PG12) in apples at $4^{\circ} \mathrm{C}$ during 30 days and after this period kept at $25^{\circ} \mathrm{C}$ after 3 days.

The strain PE51 did not produce patulin after 30 days at 4 ${ }^{\circ} \mathrm{C}$. However, when kept at $25{ }^{\circ} \mathrm{C}$ during 3 days occurred significantly patulin production $\left(370 \pm 16 \mu \mathrm{g} \cdot \mathrm{kg}^{-1}\right)$. In contrast, the strains PE8 did not produced patulin either after 30 days at $4{ }^{\circ} \mathrm{C}$ or after $25^{\circ} \mathrm{C}$ during 3 days (Figure $3 b$ ).

In the present work we analyzed the decayed area and 1 $\mathrm{cm}$ below the decayed tissue of apples. Laidou et al. (8) demonstrated that patulin is also found in sound tissues. Rychlik and Schieberle (19) showed that the diffusion of patulin differs depending on the matrix. No diffusion of patulin was observed when the toxin was applied directly to a decayed area of apple. Marin et al. (10) detected 2-3\% of patulin from the surrounding area of decay. Bandoh et al. (3) showed that patulin accumulation is confined to the decayed area. Therefore it is very important to remove any apples or parts of the apple with visible visible fungal decay before processing.

It is important to study patulin production in a specific apple cultivar and strain of $P$. expansum and $P$. griseofulvum previously confirmed to be patulin producer. This is the first report about effect of storage temperature on growth rate and 
conditions of patulin production by $P$. griseofulvum. This study is focused on normal atmosphere cold storage condition. However, studies have used controlled atmosphere to fruit storage, this practice is becoming common and it is an efficient practice to prevent or decrease patulin production $(2,13)$.

Several studies have assayed the efficiency of some methods to reduce patulin content in fruit before processing. Removal of decayed tissue or washing before processing reduces patulin levels in final products (23). In our previous research we evaluated juices produced by an industry using apple naturally contaminated with $P$. expansum and $P$. griseofulvum. Although the overall loss of patulin through processing from apple to apple juice was $75.2 \%$, all samples were found to exceed patulin concentration of $10 \mu \mathrm{g} . \mathrm{L}^{-1}$, which is the maximum permitted concentration established for apple products intended for young children by The Commission of the European Communities (28). Thus, the use of apples with patulin levels higher than $200 \mu \mathrm{g} . \mathrm{L}^{-1}$ can result in juices with levels of this toxin above the recommended. Patulin levels higher than $200 \mu \mathrm{g} . \mathrm{L}^{-1}$ were found in apples inoculated with Penicillium strains only after a day at $25^{\circ} \mathrm{C}$.

Fruits are usually stored at refrigerator temperature mainly to delay senescence but also to suppress postharvest decay. Although decay proceeds slowly at cold storage temperatures, rapid development occurs when the fruit is transferred to a warm environment. The storage at $25{ }^{\circ} \mathrm{C}$ after cold storage leads to a rapid development of decayed tissue and patulin accumulation. These results confirm that time in which apples were kept at ambient deck storage before being processed is critical in order to prevent patulin accumulation.

In Brazil, apples supplied to apple juice elaborators include those rejected for fresh consumption. Ground harvested apples or apples with evident lesion when harvested are diverted to apple processing plants. Storage at room temperature leads to a rapid development of decayed tissue and patulin accumulation in apples. Then, storage time is a critical control point (CCP) in apple juice production. Considering our results, industries should assess quality of apples entering the processing plant and minimize the ambient deck storage of fruits.

\section{ACKNOWLEDGEMENTS}

The authors thank the Toxicology Laboratory (LabTox) at the Institute of Food Science and Technology of the Federal University of Rio Grande do Sul, the Conselho Nacional de Desenvolvimento Científico e Tecnológico ( $\mathrm{CNPq}$ ) for the financial support and Coordenadoria para Aperfeiçoamento de Pessoal de Nível Superior (CAPES) for the scholarships.

\section{REFERENCES}

1. AOAC. (2000). Official Methods on Analysis of AOAC International. Method 974.18 Patulin in apple juice Thin-Layer Chromatographic Method, Natural Toxins, Chapter 49.

2. Baert, K.; Valero, A.; Meulenaer, B.; Samapundo, S.; Ahmed, M.M.; Bo, L.; Debevere J.; Devlieghere F. (2007). Influence of storage conditions of apples on growth and patulin production by Penicillium expansum. Int. J. Food Microbiol., 119, 170-181.

3. Bandoh, S.; Takeuchi, M.; Ohsawa, K.; Higashihara, K.; Kawamoto, Y.; Goto, T. (2009). Patulin distribution in decayed apple and its reduction. Int. Biodeterior. Biodegrad., 63, 379-382.

4. Ciegler, A.; Beckwith, A.C.; Jackson, L.K. (1976). Teratogenicity of patulin and patulin adducts formed with cysteine. App. Environ. Microbiol., 31, 664-667.

5. Jackson, L.S., Beacham-Bowden, T., Keller, S.E., Adhikai, C., Taylor, K.T., Chirtel, S.J.; Merker, R.I. (2003). Apple quality, storage and washing treatments affect patulin levels in apple cider. J. Food Prot., 66, 618:624.

6. Hoeltz, M.; Welke, J.E.; Dottori, H.A.; Noll,I.B. (2009). Photometric procedure for quantitative analysis of aflatoxin B1 in peanuts by thinlayer chromatography using charge coupled device detector. Quím. Nova, in press.

7. Kawashima, L.M.; Soares, V.L.M.; Massaguer, P.R. (2002). The development of an analytical method for two mycotoxins, patulin and verruculogen, and survey of their presence in commercial tomato pulp. Braz. J. Microbiol., 33, 269-273.

8. Laidou, I.A.; Thanassoulpopoulos, C.C.; Liakopoulo-Kyriakides, M. (2001). Diffusion of patulin in the flesh pears inoculated with four postharvest pathogens. J. Phytopathol., 149, 457-461.

9. Liu, B.H.; Yu, F.Y.; Wu, T.S.; Li, S Y.; Su, M.C.; Wang, M.C. (2003). Evaluation of genotoxic risk and oxidative DNA damage in mammalian cells exposed to mycotoxins patulin and citrinin. Toxicol. Appl. Pharmacol., 191, 255-263.

10. Marin, S.; Morales, H.; Hasan, H.A.H.; Ramos, A.J.; Sanchis, V. (2006). 
Patulin distribution in Fuji and Golden apples contaminated with Penicillium expansum. Food Addit. Contamin., 23, 1316-1322.

11. Martins, M.L.; Gimeno, A.; Martins, H.M.; Bernardo, F. (2002). Cooccurrence of patulin and citrinin in Portuguese apples with rotten spots. Food Addit. Contamin., 19, 568-574.

12. Mccallum, J.L.; Tsao, R.; Zhou, T. (2002). Factors affecting patulin production by Penicillium expansum. J. Food Prot., 65, 1937-1942.

13. Morales, H.; Sanchis, V.; Rovira, A.; Ramos, A.J.; Marín, S. (2007) Patulin accumulation in apples during postharvest: Effect of controlled atmosphere storage and fungicide treatments. Food Control, 18, 14431448 .

14. Morales, H.; Barros, G.; Marín, S.; Chulze, S.; Ramos, A.J.; Sanchis, V. (2008) Effects of apple and pear varieties and $\mathrm{pH}$ on patulin accumulation by Penicillium expansum. J. Sci. Food Agric., 88, 27382743.

15. Northold, M.D.; Van Egmond, H.P.; Paulsch, W.E. (1978). Patulin production by some fungal species in relation to water activity and temperature. J. Food Prot., 41, 885-890.

16. Oliveira, R.C.; Bando, E.; Machinski Junior, M. (2007). Intralaboratory optimization and validation of a method for patulin determination in grapes by thin-layer chromatography. Braz. J. Microbiol., 38, 304-308.

17. Paster, N.; Huppert, D.; Barkai-Golan, B. (1995). Production of patulin by different strains of Penicillium expansum in pear and apple cultivars stored at different temperatures and modified atmospheres. Food Addit. Contamin., 12, 51-58.

18. Pepeljnjak, S.; Segvic, M.; Ozegovic, L. (2002). Citrininotoxinogenicity of Penicillium spp. isolated from decaying apples. Braz. J. Microbiol., 33, 134-137.

19. Pitt, J. I.; Hocking, A.D. (1997). Fungi and food spoilage. London: Blackie Academic \& Professional.

20. Rychlik, M.; Schieberle, P. (2001). Model studies on the diffusion behavior of the mycotoxin patulin in apples, tomatoes, and wheat bread. Eur. Food Res. Technol., 212, 274-278.

21. Salomão, B.C.M.; Aragão, G.M.F.; Churey, J.J.; Padilha-Zakour, O.I.; Worobo, R.W. (2009) Influence of storage temperature and apple variety on patulin production by Penicillium expansum. J. Food Protec., 72, 1030-1036.

22. Speijers, G.J.A.; Franken, M.A.M.; Van Leeuwen, F.X.R. (1988). Subacute toxicity study of patulin in the rat: effects on the kidney and the gastrointestinal tract. Food Chem. Toxicol., 26, 23-30.

23. Sydenham, E.W.; Vismer, H.F.; Marasas, W.F.O.; Brown, N.; Schlechter, M.; Van Der Westhuizen, I.; Rheeder, J.P. (1995). Reduction of patulin in apple juice samples - influence of initial processing. Food Control, 6, 195-200.

24. The Commission of The European Communities. (2006). No. 1881/2006 - L364/17. Official Journal European Union, 13-14.

25. Vero, S.; Mondino, P.; Burgueño, J.; Soubes, M.; Wisniewski, M. (2002). Characterization of biocontrol activity of two yeast strains from Uruguay against blue mold of apple. Postharv. Biol. Technol., 26, 91-98.

26. Welke, J.E.; Hoeltz, M.; Dottori, H.A. Noll, I.B. (2009). Fungi and patulin in apples and the role of processing on patulin levels in juices: a study on naturally contaminated apples. J. Food Quality, in press.

27. Welke, J.E.; Hoeltz, M.; Dottori, H.A.; Noll, I.B. (2009). Quantitative analysis of patulin in apple juice by thin-layer chromatography using charge coupled device detector. Food Addit. Contamin., 26, 754-758.

28. Welke, J.E.; Hoeltz, M.; Dottori, H.A.; Noll, I.B. (2009). Effect of processing stages of apple juice concentrate on patulin levels. Food Control, 20, 48-52.

29. Welke, J.E.; Hoeltz, M.; Dottori, H.A.; Noll, I.B. (2009). Ocorrência, aspectos toxicológicos, métodos analíticos e controle da patulina em alimentos. Cienc. Rural, 39, 300-308. 